\title{
IAMJ
}

INTERNATIONAL

AYURVEDIC

MEDICAL JOURNAL

\section{HERBAL DRUG TREATMENT ON KRODH (ANGER) - A REVIEW STUDY}

\author{
Sanika R. Pandit ${ }^{1}$, Rajesh Kolarkar ${ }^{2}$ \\ ${ }^{1}$ P.G. Scholar Ayurved Samhita And Siddhanta Dept. Y.M.T. Ayurvedic Medical College, Kharghar, \\ Maharashtra, India \\ ${ }^{2}$ Guide and H.O.D. Ayurved Samhita And Siddhanta Dept. Y.M.T. Ayurvedic Medical College, Kharghar, \\ Maharashtra, India
}

Corresponding Author: sanu9rp@gmail.com

https://doi.org/10.46607/iamj08p5042021

(Published online: May 2021)

Open Access

(C) International Ayurvedic Medical Journal, India 2021

Article Received: 31/03/2021 - Peer Reviewed: 06/05/2021 - Accepted for Publication: 07/05/2021

Check for updates

\begin{abstract}
Psychiatry is a branch which is yet to be explored in Ayurveda. The existing medicines used in Modern system of medicine have serious adverse effects. Hence it is the need of the hour to explore medicines in this context. In Ayurveda Manovaha srotas deals with mind and psychology. Components of Manovaha srotas include Pran Vayu, Udaan Vayu, Vyaan Vayu, Sadhak Pitta and Tarpak kaph. Abnormality in any of these components disturbs mind and causes various psychological disorders. Sadhak Pitta - a subtype of Pitta Dosh is associated with mind and emotions. Emotions like courage, fear, anger, happiness comes under the influence of Sadhak Pitta. Variations in these emotions are the root cause of any psychological imbalance. In this study an attempt is made to study Krodh (anger) in detail and to explore the probable Dravya (Herbal drugs) which can be used to treat anger. Although Yoga and Aachar Rasayan described in Ayurveda have a great influence on emotions and mind, this study attempts to find herbal drugs acting on the Anger emotion as per Ayurveda. The study was carried out by reviewing various Ayurvedic Samhitas and Nighantus along with corresponding Modern Research articles on it. The aim of this study is to collect the scattered information of Dravya (Herbal Drugs) mentioned in the samhitas which can be used to treat anger emotion and make them available for further research under one single platform. A total of 6 drugs are studied in this study.
\end{abstract}


Keywords: Ayurveda, Psychiatry, Manovaha srotas, Emotions, Anger, Dravya, Herbal Drugs.

\section{INTRODUCTION}

For all individuals, mental, physical and social health are vital and interwoven strands of life ${ }^{1}$. Health is defined as a state of physical, mental and social wellbeing in which disease and infirmity are absent ${ }^{2}$. Now days the percentage of people suffering from Mental health problems is increasing. Changing lifestyle and increased levels of stress caused while adapting to these changes has taken a toll on mental health of people. Unfortunately, not much importance and attention is given to mental health as it is given to physical health maybe because of social stigma and unacceptance. As many as 450 million people suffer from a mental or behavioral disorder ${ }^{1}$. [The psychiatric drugs are designed to correct underlying neuropathological disease processes by restoring neural communication by modulating the brain's chemical messengers and neurotransmitters. These changes can be accompanied by debilitating neurological impairments and life-threatening effects. Given the pervasiveness of their use, psychiatric medication can either alleviate or exacerbate mental illness. One reason behind the mixed success of psychiatric medication stems from the fact that the mechanisms by which they modify the brain operations are poorly understood. $]^{3}$ Hence it is need of the day to explore alternative medicines in this field which have minimal or no adverse effects.

There is a vast scope for exploring Psychiatry in Ayurveda. Because the emotions influence behavior to a large extent, it is need of the hour to find medicines working on emotions to prevent behavioral disorders. Anger is a primary human emotion we all experience from time to time ${ }^{4}$. Anger is felt when we feel threatened due to physical conflict, injustice, humiliation or betrayal. It is rightly said that' Overcome angry by non-anger, overcome the wicked by goodness, overcome the miser by generosity, overcome the liar by truth ${ }^{5}$.The physiology of anger is studied and herbal drugs which can act on this emotion are explored in this study.

\section{Materials and Methods}

Literature review done from Charak Samhita, Sushrut Samhita, Vagbhat and their tika along with Bhav prakash Nighantu and other Dravyagun Granthas.

\section{Aim and Objectives}

1. To study anger emotion in detail.

2. To find probable Ayurvedic drugs acting on anger emotion.

3. To make probable comparison of these Ayurvedic drugs with Modern research on these drugs and find their correlation if any.

\section{Literature Review}

As per Charak chakrapani tika, Krodh is defined as Krodhaha Pradvesho yena Prajvalitam Iva aatmanam manyate $^{6}$ which means Jealousy which burns the soul like fire is called anger. As per Ayurveda, Krodh is an emotion influenced by Raj gun and Pitta Dosh ${ }^{7}$. As per Paanchabhautikatva, Anger or Krodh is described as 'Aagneya', Charak describes effects of Anger on our body. He says angry person suffers from following ${ }^{9}$.

1) Maans shithilata (Muscle laxity).

2) Vimuchyati sandhi (Redemption of joints).

3) Rakta Vidaaha (Increased heat in blood).

4) Med Vilayan (Melting of fats).

5) Majja kshay in sandhi asthi (Bones and joints become hollow).

6) Decreased Shukrastraav or decreased shukrotpatti (Decreased sperm count or decreased semen secretion).

7) Oaj kshay (Decreased oaj).

Apart from these symptoms, Ayurveda also describes Anger as a cause of Paalitya ${ }^{10}$ (Graying of hair), Vyanga $^{11}$ (Melasma), Pittaj Headache ${ }^{12}$ (Headache because of vitiated Pitta dosh), Rakta dushti ${ }^{13}$ (Vitiation of blood), Pittaj Prameha ${ }^{14}$, Pittaj Jwar ${ }^{15}$, Depression $^{16}$, Raktapitta ${ }^{17}$ (Epistaxis), Shukra dushti hetu $^{18}$, Stanya dushti hetu ${ }^{19}$.

So as per Ayurvedic physiology while finding herbal drugs for Krodh emotion, we need to find drugs satisfying 3 Criteria- 
1) Drugs acting on mind. (Since Mind is described as adhisthaan of $\mathrm{krodh}^{20}$ )

2) Drugs decreasing Rajo gun ${ }^{7}$ (Satva gun pradhaan).

3) Drugs decreasing tikshna gun of Pitta since it is Aagneya ${ }^{8}$ (Saumya/manda drugs).

Now as per Modern Physiology of Anger, the mechanism occurring in our body when a person is angry is as follows-

When a person becomes angry, neurotransmitter chemicals known as Catecholamines (Dopamine, Nor epinephrine, Serotonin) are released in the brain causing burst of energy lasting for several minutes ${ }^{21}$. At the same time heart accelerates, Blood pressure rises, rate of breathing increases. In quick succession, additional brain neurotransmitters and hormones (Adrenaline and nor adrenaline) are released which trigger a lasting state of arousal ${ }^{21}$. The brain chemical serotonin has long been known to play an important role in regulating anger and aggression ${ }^{22}$. Decrease in Serotonin concentration leads to Anger and Aggressive behavior $^{22}$. In animal studies treatment with selective serotonin receptor agonist compound has been found to restore normal functioning of these receptors and suppress aggressive behavior. The substrate for both fear and anger is nor epinephrine ${ }^{23}$. Nor epinephrine release induces fight (anger) or flight (fear). Fear and Anger are twin emotions coming from the same neuromodulator nor epinephrine and they always come together at a stress ${ }^{23}$. Nor epinephrine and Dopamine are usually released to induce anger. Acetylcholine is a cognitive part of emotion which gives the subject a calming and soothing effect.

So as per Modern physiology while finding drugs for anger emotion we need to find drugs satisfying any of the following 2 criteria-

1) Drugs increasing level of serotonin.

2) Drugs increasing Acetylcholine (Drugs inhibiting the activity of Acetyl cholinesterase).

\section{Probable Ayurvedic Drugs acting on Anger emotion and their Modern correlation.}

\begin{tabular}{|c|c|c|}
\hline NAME & Ayurvedic view & Modern Drug research \\
\hline $\begin{array}{l}\text { 1) Aamra } \\
\text { Latin name- } \\
\text { Mangifera in- } \\
\text { dica }\end{array}$ & $\begin{array}{l}\text { Properties- Madhur-Sheet-Madhur } \\
\text { Guru Snigdha }{ }^{24} \text {. } \\
\text { Because of these properties, it is de- } \\
\text { creases vitiated raj gun of Vaat dosh } \\
\text { and tikshna gun of Pitta. } \\
\text { Also, it acts on mind and hence further } \\
\text { research needs to be done if this drug } \\
\text { can be used on anger. }\end{array}$ & $\begin{array}{l}\text { It can cause modulation of mood via interaction with serotonin } \\
\text { receptors and dopamine receptors }{ }^{25} \text {. } \\
\text { Also, it contains COMT which inhibits Adrenaline and can be } \\
\text { used to treat mood and addiction disorders }{ }^{25} \text {. }\end{array}$ \\
\hline $\begin{array}{l}\text { 2) Kadali } \\
\text { Latin name- } \\
\text { Musa acimina- } \\
\text { ta }\end{array}$ & $\begin{array}{l}\text { Properties- Madhur-Sheet-Madhur } \\
\text { Guru Snigdha }{ }^{26 .} \text { Majja Dhatu Shamak } \\
\text { (Soothes the nervous system) } \\
\text { Because of these properties it decreases } \\
\text { vitiated Vaat and pitta dosh and hence } \\
\text { can be used in treatment of anger. }\end{array}$ & $\begin{array}{l}\text { It inhibits the activity of the enzyme acetyl cholinesterase and } \\
\text { thus makes acetylcholine available which has a calm and } \\
\text { soothing effect on body }{ }^{27} \text {. Also, it contains Serotonin and nor } \\
\text { epinephrine in Fruit pulp which helps in soothing anger }{ }^{28} \text {. }\end{array}$ \\
\hline $\begin{array}{l}\text { 3) Chanchu } \\
\text { Latin name- } \\
\text { Corchorus } \\
\text { depressus. }\end{array}$ & $\begin{array}{l}\text { Properties- Madhur-Sheet-Madhur } \\
\text { Guru Snigdha Pichchil Tridosh } \\
\text { shamak }^{29} \text {. } \\
\text { Because of these properties it decreases } \\
\text { Vaat and pitta dosh and hence can be } \\
\text { used in treatment of anger. }\end{array}$ & $\begin{array}{l}\text { It inhibits the activities of acetyl cholinesterase and thus makes } \\
\text { acetylcholine available which has a calm and soothing effect } \\
\text { on body }^{30} \text {. }\end{array}$ \\
\hline $\begin{array}{l}\text { 4) Draaksha } \\
\text { Latin name- } \\
\text { Vitis vinifera. }\end{array}$ & $\begin{array}{l}\text { Properties- Madhur-Sheet-Madhur } \\
\text { Guru Snigdha Mrudu }{ }^{31} \text {. } \\
\text { Because of these properties it decreases } \\
\text { tikshna gun of pitta; also, it is decreases }\end{array}$ & $\begin{array}{l}\text { Vitis vinifera increases level of serotonin and Nor Adrenaline } \\
\text { and thus helps in soothing and calming a person and effective- } \\
\text { ly decreases bursts of anger }{ }^{32} \text {.Vitis vinifera juice increases } \\
\text { levels of both Serotonin and nor adrenaline }{ }^{33} \text {. }\end{array}$ \\
\hline
\end{tabular}




\begin{tabular}{|c|c|c|}
\hline & $\begin{array}{l}\text { Vaat dosh and hence can be used in the } \\
\text { treatment of anger. }\end{array}$ & \\
\hline $\begin{array}{l}\text { 5) Naarikel } \\
\text { Latin Name- } \\
\text { Cocos nucifera }\end{array}$ & $\begin{array}{l}\text { Properties- Madhur-Sheet-Madhur } \\
\text { Guru Snigdha Majja Dhatu Balya }{ }^{34} \\
\text { (Strengthens the nervous system) } \\
\text { Because of these properties it can help } \\
\text { in treating anger. }\end{array}$ & $\begin{array}{l}\text { It increases the level of serotonin and thus soothes anger and } \\
\text { aggression }{ }^{35} \text {. } \\
\text { Also, Young coconut water ameliorates depression via modu- } \\
\text { lation of Neurotransmitters which means it has a soothing ef- } \\
\text { fect on mind }{ }^{36} \text {. }\end{array}$ \\
\hline $\begin{array}{l}\text { 6) Bala } \\
\text { Latin Name- } \\
\text { Sida cordifolia }\end{array}$ & $\begin{array}{l}\text { Properties- Madhur-Sheet-Madhur } \\
\text { Guru Snigdha Pichchil Vaat Pitta } \\
\text { shamak }{ }^{37} \text {. } \\
\text { Because of these properties it can help } \\
\text { in soothing anger. }\end{array}$ & $\begin{array}{l}\text { It inhibits the activity of Acetyl cholinesterase and hence } \\
\text { makes acetylcholine available which has a calm and soothing } \\
\text { effect on body }{ }^{38} \text {. }\end{array}$ \\
\hline
\end{tabular}

\section{DISCUSSION}

1) As per Ayurvedic Physiology, Anger (Krodh) is vitiation of Shaarir dosh Pitta by Tikshna Ushna gun and vitiation of Manas dosh Raj.

2) As per Modern Physiology, Neurotransmitter chemicals called Catecholamines (Dopamine, nor epinephrine and Serotonin) are released in brain causing burst of anger emotion.

3) Also decrease in Serotonin concentration in brain causes anger and aggression.

4) In this study, probable herbal drugs acting on Krodh by Ayurvedic physiology as well as acting on Anger by Modern Physiology are selected and studied.

5) Probable comparison is made of the same drug as per both Ayurvedic and Modern Physiology. Probable Ayurvedic drugs are selected and corresponding modern correlation and research done on them is studied.

6) All probable drugs acting on Anger emotion are brought together under one single platform and made available for further research.

\section{CONCLUSION}

Anger emotion is studied in detail as per both Ayurveda and Modern system of medicine and a list of probable drugs acting on them is made. Only drugs satisfying both Ayurvedic and Modern criteria are selected. Although these drugs may probably act on anger emotion; only Drug therapy is not sufficient in the treatment of psychological disorders. Cultivation or training of mind is equally important. Developing
Maitreebhav vritti (Metta) i.e. love, kindness, empathy is also required. All this comes under Satvavajay chikitsa in Ayurveda. Also maintaining Dhaatusamyata i.e. balance of Shaarir as well as Maanas doshas plays a vital role. From Modern point of view, REBT (Rational Emotive Behavior Therapy), CBT (Cognitive Behavior Therapy), Gestalt Therapy etc. play an important role. Further research needs to be done to check the validity of these drugs in this context so that these drugs can be used along with the Satvavajay chikitsa in Ayurveda to give better results in emotional disorders.

Conflict of Interest- None declared.

\section{REFERENCES}

1. World Health Organization. Mental health by World Health Organization. [Internet]Geneva. Available from URL- www.who.int.

2. WIKIPEDIA. HEALTH- WIKIPEDIA [Internet]. Available from URL- en.m.wikipedia.org.

3. Koustuv Saha, Benjamin Sugar,[...], and Munmun De Chaudhury; A Social media study on effects of Psychiatric Medication use. Proc Int AAAI Conf Weblogs Soc Media.2019 June 7;13: 440-451.

4. La Velle Hendricks, Sam Bore, Dean Aslinia, et al. The effects of Anger on the brain and body. National Forum Journal of Counseling and Addiction Volume 2, Number 1,2013.

5. The Dhammapada: Buddha's path of Wisdom shlok 223. Buddha Dharma Education Association Inc.

6. Charak Samhita Sutrasthan Adhyay 7 shlok 27 tika by Chakrapani Chaukhamba Prakashan Edition 2016

7. Charak Samhita Sutrasthan Adhyay 8 shlok 5 tika by Chakrapani Chaukhamba Prakashan Edition 2016 
8. Charak Samhita Nidansthan Adhyay 1 shlok 7 tika by Chakrapani Chaukhamba Prakashan Edition 2016

9. Charak Samhita Chikitsasthan Adhyay 1 paad 2 shlok 3 tika by Chakrapani Chaukhamba Prakashan Edition 2016.

10. Sushrut Samhita Nidansthan Adhyay 13 shlok 37 Translation by Priyavrat Sharma Chaukhamba Prakashan Edition 2012.

11. Sushrut Samhita Nidansthan Adhyay 13 shlok 45Translation By Priyavrat Sharma Chaukhamba Prakashan Edition 2012.

12. Charak Samhita Sutrasthan Adhyay 17 shlok 22 tika by Chakrapani Chaukhamba Prakashan Edition 2016.

13. Charak Samhita Sutrasthan Adhyay 24 shlok 9 tika by Chakrapani Chaukhamba Prakashan Edition 2016.

14. Charak Samhita Nidansthan Adhyay 4 shlok 24 tika by Chakrapani Chaukhamba Prakashan Edition 2016.

15. Charak Samhita Nidansthan Adhyay 1 shlok 22 tika by Chakrapani Chaukhamba Prakashan Edition 2016.

16. Sushrut Samhita Kalpasthan Adhyay 3 shlok 19 Translation by Priyavrat Sharma Chaukhamba Prakashan Edition 2012.

17. Sushrut Samhita Uttartantra Adhyay 45 shlok 3 Translation by Priyavrat Sharma Chaukhamba Prakashan Edition 2012.

18. Charak Samhita Chikitsasthan Adhyay 30 shlok 137 tika by Chakrapani Chaukhamba Prakashan Edition 2016.

19. Charak Samhita Chikitsasthan Adhyay 30 shlok 137 tika by Chakrapani Chaukhamba Prakashan Edition 2016.

20. Sushrut Samhita Sutrasthan Adhyay 1 shlok 26 Translation by Priyavrat Sharma Chaukhamba Prakashan Edition 2012.

21. An American Addiction Centers Resource. Physiology of Anger [Internet] San Diego, CA. Available on URLwww.mentalhelp.net

22. Brain chemicals involved in Aggression identified may lead to new treatment. Science daily, Society for Neuroscience Nov 72007.

23. Simeng Gu, Fushun Wang, et al. Differentiation of Primary emotions through Neuro modulators- Review of Literature: International Journal of Neurological Research; May13,2015.

24. Gogate- Dravyagun Vidnyaan Page 275 Edition 2008.

25. Laura Lopez Rios, CNS Activities of extract of Mangifera Indica L. Journal of Ethno pharmacology, Vol.260, 5 Oct 2020.

26. Gogate- Dravyagun Vidnyaan Page 325 Edition 2008.

27. Ibukun Ayoola Oresanya,Mubo Sonibare,Badara Gueye, et al. Isolation of flavenoids from Musa acuminate colla and the in vitro inhibitory effects of its leaf and fruit fractions on free radicals, acetylcholinesterase, 15-lipoxygenase and carbohydrate hydrolyzing enzymes. Journal of food and biochemistry.44 (1) January 2020.
28. Bashir Ado Ahmad, Umar Abdullahi Zakariyya,Mujaheed Abubakar, Musbahu Muhammad Sani et al. Pharmacological activities of Banana. Published on 12/09/2019. Available URL- intechopen.com

29. Gogate- Dravyagun Vidnyaan Page 388 Edition 2008.

30. Samina Afzal, Bashir Ahmad Chaudhary, Ashfaq Ahmad,et al. Antioxidant ,acetylcholinesterase and alphaglucosidase inhibitory activities of Corchorus depressus. Pharmacognosy magazine 13(52),647,2017.

31. Gogate- Dravyagun Vidnyaan Page 447 Edition 2008.

32. Gharib Naseri Mohammad Kazem. Effect of Vitis vinifera leaf extract on per fused frog heart. Zahedan journal of research in medical sciences 2004. Available from- https://www.sid.ir/en/journal/View paper.aspx?id=42459>

33. Muhammad Aslam, Nuzhat Sultana. Vitis vinifera juice ameliorates depression like behavior in mice by modulating biogenic amine neurotransmitters. Bangladesh journal of pharmacology 10(4), 753-758,2015.

34. Gogate- Dravyagun Vidnyaan Page 472 Edition 2008.

35. Virupanagouda P Patil, Nanjappaiah Hankuntimath, et al. Investigation of anti stress activity of cocos nucifera endocarp. September 2018. Available on www.researchgate.net/publication/327635897.

36. Sadia Saleem Rao, Rahila Najam. Young coconut water ameliorates depression via modulation of neurotransmitters: possible mechanism of action. Metabolic brain diseases. Published on 05/07/2016. Available on https://link.springer.com/article/10.1007\%2Fs11011016-9866-2.

37. Gogate- Dravyagun Vidnyaan Page 522 Edition 2008.

38. B Vinutha, D Prashanth, K Salma, et al. Screening of selected Indian medicinal plants for acetyl cholinesterase inhibitory activity. Journal of ethnopharmacology109(2),359-363,2007.

\section{Source of Support: Nil Conflict of Interest: None Declared}

How to cite this URL: Sanika R. Pandit \& Rajesh Kolarkar: Herbal Drug Treatment On Krodh (Anger) - A Review Study. International Ayurvedic Medical Journal \{online\} 2021 \{cited May, 2021\} Available from: http://www.iamj.in/posts/images/upload/2919 2923.pdf 